\title{
Variability and interactions of phytoplankton and bacterioplankton in the Antarctic neritic area
}

\author{
Michel Fiala, Daniel Delille \\ Observatoire Océanologique de Banyuls, Université P. et M. Curie, U.R.A. CNRS 117, Laboratoire Arago, \\ F-66650 Banyuls-sur-Mer, France
}

\begin{abstract}
The distributions of phytoplankton biomass and bacterial populations were investigated at 37 stations on the continental shelf of Terre Adélie (Antarctica) during Austral summer 1989. Despite a potentially favourable environment, phytoplankton biomass was relatively low. Surface chlorophyll a values ranged from $1.2 \mathrm{mg} \mathrm{m}^{-3}$ in the coastal area, with a maximum of $2.5 \mathrm{mg} \mathrm{m}^{-3}$ in the vicinity of the penguin rookeries, to only $0.2 \mathrm{mg} \mathrm{m}^{-3} 70 \mathrm{~km}$ offshore. In the Pointe Géologie Archipelago, diatoms larger than $10 \mu \mathrm{m}$ were predominant and represented more than $80 \%$ of the total biomass. In offshore waters, these large cells represented only $38 \%$ of the total biomass with $59 \%$ of the biomass in the 1 to $10 \mu \mathrm{m}$ fraction. Total bacterial abundance ranged from $9.4 \times 10^{9}$ to $1.0 \times 10^{11} \mathrm{cells} \mathrm{m}^{-3}$ and heterotrophic bacteria ranged from $1.4 \times 10^{6}$ to $7.7 \times 10^{8}$ colony forming units $\mathrm{m}^{-3}$ Frequency of dividing cells ranged from 0.8 to $6.6 \%$. The highest numbers of heterotrophic bacteria were recorded in the immediate vicinity of penguin rookeries and the lowest in offshore waters. Bacterial biomass represents between 2 to $15 \%$ of total microbial biomass in offshore waters and up to $30 \%$ in the coastal area. There was no direct correlation between bacterial and phytoplanktonic standing stocks. This lack of relationship can be explained by considering the differences in scale. It is suggested that in the coastal area where large diatoms are dominant, the bacteria are mainly dependant on organic matter introduced by bird manuring. On the other hand, in offshore waters where the dominant phytoplankton fraction under $10 \mu \mathrm{m}$ represents a large part of the microbial loop, an indirect relationship between algae and bacteria may be expected.
\end{abstract}

\section{INTRODUCTION}

Phytoplankton and bacterioplankton are key elements in the pelagic marine ecosystem. Phytoplankton abundance may be influenced by nutrient availability, temperature, light levels, grazers, interactions with bacteria, sinking, parasites, allelopathy and watercolumn physics (Harris 1986). Mechanisms that determine variations in bacterial abundance, usually hypothesized to be related to temperature, zooplankton grazing and availability of substrate (Pick \& Caron 1987, Sherr et al. 1988, Kuosa \& Kivi 1989), are less clear Recent studies show, however, that bacterial abundance is consistently related to algal abundance and productivity and to sestonic organic carbon (Cole et al. 1988, Delille 1990a). In the Antarctic neritic area 2 other factors may play a significant role in the interactions among phytoplankton and bacterioplankton: on the one hand, the variations of the physical and chemical environment due to seasonal ice cover fluctu- ations which influence trophic dynamics within the 2 communities (Rivkin et al. 1989, Satoh et al. 1989); on the other hand, the transfer of nutritive material from a large zone of the Antarctic Ocean to a restricted area by penguins and other birds. While the influence of bird manuring on surrounding marine areas has been largely neglected, previous experiments have demonstrated the impact of ornithogenic soils on the seawater bacterial microflora (Delille 1987, 1990b).

The pathways that mediate the transfer of organic and inorganic nutrients between the primary producers and bacteria in seawater are extremely complex and include numerous feedback mechanisms. Heterotrophic bacteria in the offshore euphotic zone are largely reliant on phytoplankton for their energy supply, either through excretion of dissolved organic matter (Lancelot \& Billen 1984, Kuosa \& Kivi 1989, Suttle et al. 1991) or by decomposition of dead phytoplankton cells (Riemann \& Sondergaard 1986, Jumars et al. 1989). It is therefore logical to expect bacteria to 
respond to variations in growth and abundance of phytoplankton. On the other hand, it is generally assumed that most primary production in pelagic ecosystems is sustained by a continuous and rapid recycling of the growth-limiting inorganic nutrients. In the traditional view, bacteria have been considered the major agents effecting the rapid remineralisation of nutrients (Azam et al. 1983, Berman et al. 1987). Thus, phytoplankton growth may be related to changes in bacterial activity. However, doubts concerning the applicability of the functional role of bacteria in the remineralisation of nutrients have been raised and supported by recent studies (Taylor \& Joint 1990). Experimental and field results suggest that bacteria may act, at least temporarily, as sinks rather than as sources of nutrients (Ducklow et al. 1986). A variety of other mechanisms may also be involved in determining the observed small-scale horizontal distribution of phytoplankton and bacteria.

The present study was carried out in an Antarctic neritic area (Terre Adélie) during Austral summer 1989. The horizontal and vertical variability of the size fractionated phytoplankton biomass is compared with that of the heterotrophic and total bacteria to assess the degree of covariation which might indicate biological relationships.

\section{MATERIALS AND METHODS}

Sampling. This study was conducted in January 1989 during the French Polar Expedition in Terre Adelie $166^{\circ}$ $40^{\prime} \mathrm{S}, 140^{\circ} 01^{\prime}$ E). Sixteen stations distributed along
2 transects running between $66^{\circ} 40^{\prime} \mathrm{S}$ and $66^{\circ} 00^{\prime} \mathrm{S}$ (Fig. 1a) and 21 stations near the Pointe Géologie Archipelago (Fig. 1b) were sampled from 1 to 3 times. All stations were located on the continental shelf. In the vicinity of the archipelago, the depth ranged from $3 \mathrm{~m}$ (Stns 1, 2\&3) to $55 \mathrm{~m}$ ( $\operatorname{Stn} 6$ ), and in offshore waters, from 75 to $860 \mathrm{~m}$. Subsurface bacteriological samples were collected by opening a sterile glass bottle at $10 \mathrm{~cm}$ depth at every station. In addition, surface samples were collected with Niskin bottles and between surface and $50 \mathrm{~m}$ when it was possible. Measurements of submarine light penetration were performed using a Secchi disk.

The break-up of the pack ice at Terre Adélie commenced on 8 December 1988 and continued progressively until 23 December. Sample collection began $1 \mathrm{wk}$ after the complete dissociation of the pack. The month of January 1989, during which the study was carried out, was particularly clement; very little wind and exceptionally sunny conditions with a total duration of $477 \mathrm{~h}$. Solar radiation reached $81 \mathrm{k} \mathbf{J}$, a record since the first meteorological observations at the Dumont Durville Station in 1970 .

Size fractionation and chlorophyll biomass. Phytoplankton was studied by way of pigment composition analysis of different size fractions. All samples were prefiltered through a $200 \mu \mathrm{m}$ mesh to remove detritic material and larger biota. Size fractionation was accomplished by gentle vacuum filtration of $100 \mathrm{ml}$ of seawater through a series of 4 filters: Nuclepore polycarbonate membranes of $10 \mu \mathrm{m}, 3 \mu \mathrm{m}$ and $1 \mu \mathrm{m}$ and a Whatman $\mathrm{GF} / \mathrm{F}$ glass-fiber as the terminal filter.

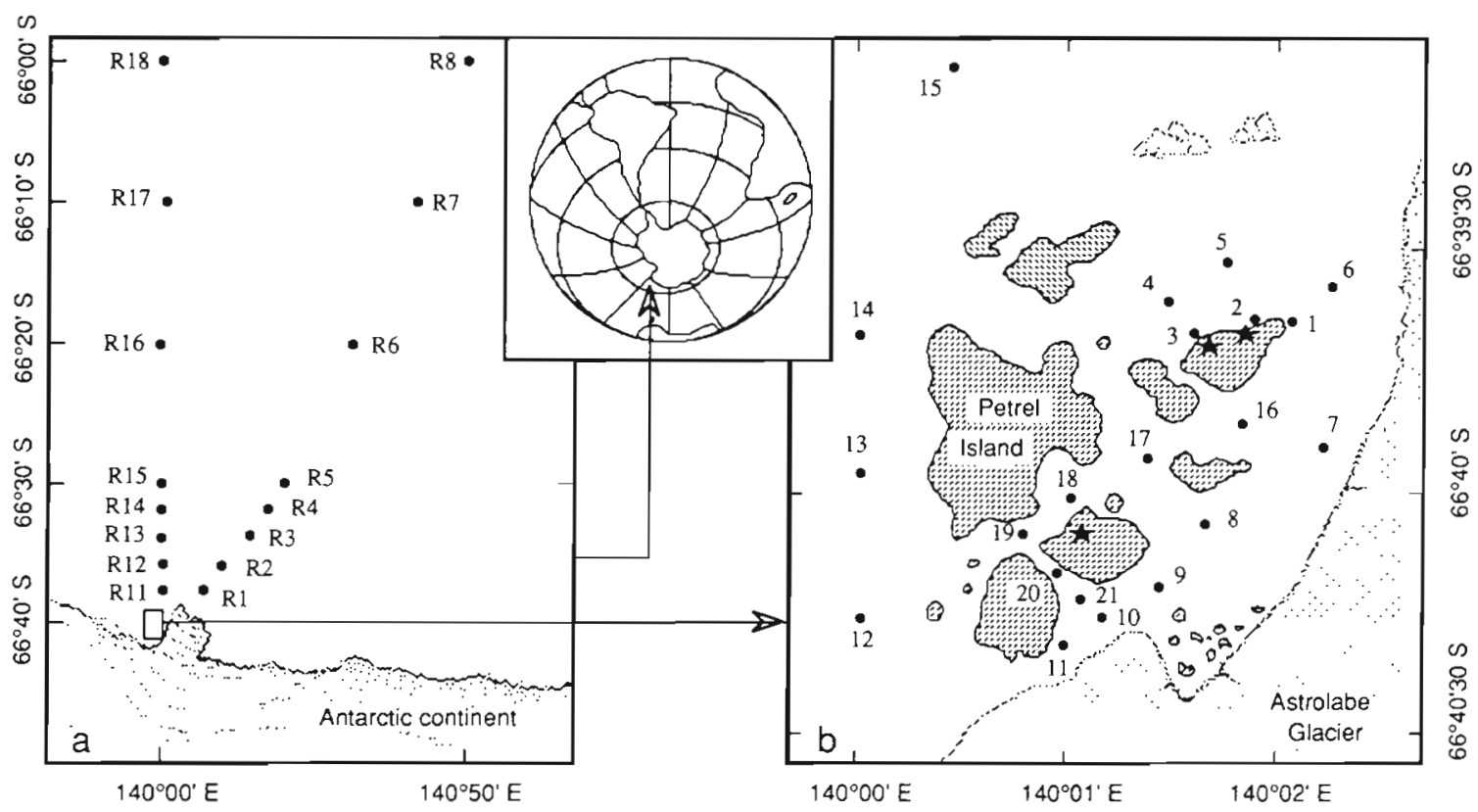

Fig. 1. Pointe Géologie Archipelago (Terre Adélie Antarctica). (a) Position of the 16 stations along the 2 transects (R1 to R8 and R1 1 to $\mathrm{R} 18$ ) between $66^{\circ} 40^{\prime} \mathrm{S}$ and $66^{\circ} 00^{\prime} \mathrm{S}$; (b) location of the 21 stations in the coastal area. Stars indicate locations of the most important penguin rookeries 
The measurements of chlorophylls and phaeopigments were carried out using the spectrofluorometric method developed by Neveux \& Panouse (1987) according to the following procedure: manual grinding of the GF/F filter in $90 \%$ acetone, extraction at $5^{\circ} \mathrm{C}$ for $2 \mathrm{~h}$ in the dark and centrifugation for $5 \mathrm{~min}$ at $3000 \times \mathrm{g}$ at $5^{\circ} \mathrm{C}$. Fluorescence was measured on a Perkin Elmer MPF 66 spectrofluorometer at 6 coupled wavelengths. Each coupled wavelength corresponded to the fluorescence excitation and emission of each analysed pigment: $c h l a$, chl $b$, chl $c$, phaeophytins $a, b$ and $c$. Fluctuations of the spectrofluorometer were corrected after each 10 samples analysed by using a solid sample of phaeophytin a in polymethylmethacrylate as reference. The apparatus was calibrated by standardization with purified pigment solutions according to Neveux \& Panouse (1987).

Phytoplankton populations. Aliquots of samples for microscopy were preserved, without any screening, with Lugol's iodine solution. Floristic determinations were done within 6 mo following the sampling using the method of Utermöhl (1958).

Particulate ATP. Seawater $(500 \mathrm{ml})$ was filtered using a $0.45 \mu \mathrm{m}$ Sartorius membrane. Adenosinetriphosphate (ATP) was extracted in boiling Tris buffer and determinated by peak height measurement of bioluminescence (Holm-Hansen \& Booth 1966) with a LKB 1250 luminometer.

Nutrients. Water samples were filtered through a $0.45 \mu \mathrm{m}$ Sartorius filter. The filtrates were subsequently frozen at $-20^{\circ} \mathrm{C}$ until laboratory analysis. Nitrates, nitrites, phosphates and silicates were assayed using the AutoAnalyser method (Treguer \& Le Corre 1975)

Particulate organic carbon. POC was oxidized in an induction furnace equipped with an infra-red detector (LECO IR 212). Samples of 2 to 41 were filtered directly upon collection using pre-combusted Whatman GF/F filters. Filters were dried in a vacuum desiccator and then stored frozen. Before measurement they were decalcified by treatment with $1 \mathrm{M} \mathrm{H}_{3} \mathrm{PO}_{4}$ at $60^{\circ} \mathrm{C}$ for $48 \mathrm{~h}$. The standard deviation calculated from 5 replicates was found to be $\leq 0.5 \%$.

Bacterial parameters. Seawater samples were analysed in the laboratory within $20 \mathrm{~min}$. Total bacteria were determined by acridine orange direct count (AODC) with an Olympus epifluorescence microscope according to the method of Hobbie et al. (1977). Particle related and free living bacteria were counted separately. Biovolumes were estimated using an ocular micrometer.

Frequency of dividing cells (FDC) was assessed using the method of Hagström et al. (1979). A minimum of 20 dividing cells per filter were counted. Although it is relatively straightforward to measure FDC, the calculation of in situ growth rate from these values is not simple. In the studied area significant correlation was observed between growth rates and FDC. Nevertheless, according to Newell \& Christian (1981), the linear regression equation depends on numerous parameters (Delille et al. 1988). A study is presently being conducted in Antarctic waters to compare the growth rates calculated from FDC and from stimulated growth of natural assemblages, with thymidine uptake. Until these investigations have been carried out, FDC data presented here only describe relative rates of bacterial production.

Viable counts of aerobic heterotrophic bacteria were made in triplicate using the spread plate technique on the 2216 E medium (Oppenheimer \& ZoBell 1952). Two sets of inoculated plates were incubated in the dark for $21 \mathrm{~d}$ at $2^{\circ} \mathrm{C}$ and for $6 \mathrm{~d}$ at $15^{\circ} \mathrm{C}$ respectively before counting colony forming units (CFU). Except in special circumstances where one may be looking for specific microbes (psychrophilic strains in this study) the knowledge gained by viable counts is minimal for biomass estimations. However, saprophyte counts are representive of a small group of active bacteria which immediately react to changes in nutrient supply; thus, they are a useful bacterial indicator (Caron et al. 1989. Delille \& Bouvy 1989, Rheinheimer et al. 1989).

\section{RESULTS}

\section{Physico-chemical data}

The average salinity of the surface water of the study area was $34.36 \%$ and the average temperature was $-0.44^{\circ} \mathrm{C}$ (Table 1). These physical characteristics are similar to those described by Gordon \& Tchernia (1972) for the Adélie coast and correspond to those of the 'antarctic continental shelf waters' described by Smith et al. (1984). There was a slight stratification of the water column with a surface layer, extending to about $12 \mathrm{~m}$, of slightly less saline water due to freshwater inputs $\left(\sigma_{t}=27.6\right)$ above a mass of colder and more saline water $\left(\sigma_{t}=27.8\right)$.

Nutrients were abundant (Table 1) with the same order of magnitude as those reported for other Antarctic areas (Tilzer et al. 1985, Nelson et al. 1989). The concentration ranges were 20 to $25 \mu \mathrm{M}$ for nitrate, 2 to $2.5 \mu \mathrm{M}$ for phosphate and 45 to $60 \mu \mathrm{M}$ for silicate (Fig. 2). Coastal POC levels were 3 times higher (mean 191 $\mathrm{mg} \mathrm{m}^{-3}$ ) than offshore concentrations, consistent with data previously obtained in oceanic Antarctic waters (Tanoue 1985, Nelson et al. 1989, Hewes et al. 1990, Bjørnsen \& Kuparinen 1991). The mean carbon:chlorophyll ratio was 155 , a high value compared with the typical ratio of 35 for phytoplankton and the usual ratios calculated for the Southern Ocean (Nelson et al. 
Table 1. Summary of the average physico-chemical and brological data in surface coastal waters of Pointe Géologie Archipelago

\begin{tabular}{|c|c|c|c|c|}
\hline \multirow[b]{2}{*}{ Temperature $\left({ }^{\circ} \mathrm{C}\right)$} & Mean $\pm S E$ & \multicolumn{2}{|c|}{ Range of values } & \multirow{2}{*}{$\begin{array}{c}n \\
60\end{array}$} \\
\hline & \pm 0.13 & -1.10 & +1.10 & \\
\hline Salinity (\%o) & \pm 0.04 & 33.84 & 34.89 & 58 \\
\hline $\mathrm{N}-\mathrm{NO}_{2}(\mu \mathrm{M})$ & \pm 0.02 & 0.00 & 0.53 & 60 \\
\hline $\mathrm{N}-\mathrm{NO}_{3}(\mu \mathrm{M})$ & \pm 0.89 & 13.30 & 29.91 & 60 \\
\hline $\mathrm{P}^{-\mathrm{PO}_{4}(u \mathrm{M})}$ & \pm 0.15 & 1.28 & 4.28 & 59 \\
\hline $\mathrm{Si}_{-} \mathrm{SiO}_{4}(\mu \mathrm{M})$ & \pm 1.83 & 36.0 & 77.8 & 60 \\
\hline $\mathrm{POC}\left(\mathrm{mg} \mathrm{m}^{-3}\right)$ & \pm 15.0 & 70.0 & 340.0 & 60 \\
\hline $\operatorname{ATP}\left(\mathrm{mg} \mathrm{m}^{-3}\right)$ & \pm 0.04 & 0.17 & 0.99 & 59 \\
\hline Chl a $\left(\mathrm{mg} \mathrm{m}^{-3}\right)$ & $1.23 \pm 0.13$ & 0.25 & 2.50 & 60 \\
\hline Total bacteria (cells $\mathrm{m}^{-3}$ ) & $3.1 \times 10^{10} \pm 1.7 \times 10^{10}$ & $9.4 \times 10^{9}$ & $1.0 \times 10^{11}$ & 59 \\
\hline Bact. biomass ( $\mathrm{mg} \mathrm{C} \mathrm{m}^{-3}$ ) & $12.4 \pm 6.8$ & 1.0 & 56.0 & 59 \\
\hline$\%$ Free living bact. ( $\%$ ) & \pm 17.0 & 44.0 & 100.0 & 59 \\
\hline $\operatorname{FDC}(\%)$ & $1.9 \pm 1.5$ & 0.8 & 6.6 & 59 \\
\hline Bact. $\left.15^{\circ} \mathrm{C}(\mathrm{CFU} \mathrm{m})^{-3}\right)$ & $8.4 \times 10^{7} \pm 5.3 \times 10^{7}$ & $1.4 \times 10^{6}$ & $1.9 \times 10^{7}$ & 48 \\
\hline Bact. $2^{\circ} \mathrm{C}\left(\mathrm{CFU} \mathrm{m}^{-3}\right)$ & $4.8 \times 10^{8} \pm 1.4 \times 10^{8}$ & $2.6 \times 10^{6}$ & $7.7 \times 10^{8}$ & 48 \\
\hline
\end{tabular}

1987). In the same way, the POC: ATP value was high (average 516) compared with a value of 250 commonly encountered (Holm-Hansen 1973). In this coastal area a large part of the particulate carbon may be composed of particle detritus resulting from soil leaching during ice melting and the penguin manure as witnessed by concentrations higher than $300 \mathrm{mg} \mathrm{m}^{-3}$ recorded in the proximity of important penguin rookeries (Fig. 2). The suspended matter load was in large part responsible for the shallow depth of the euphotic zone measured at $17 \mathrm{~m}$ for stations near the rookeries and between 20 and $24 \mathrm{~m}$ for the others stations.

Moving progressively away from the coast, the characteristics of the surface water changed due to their mixing with oceanic waters. The temperatures became positive and the salinities decreased progressively to less than $34 \%$ at $66^{\circ} \mathrm{S}$ (Fig. 3). Between $66^{\circ} 40^{\prime}$ and $66^{\circ} 30^{\prime}$, a zone of transition between continental shelf and oceanic waters, an inverse change occurred in the waters from east and west: for the eastern water mass (Transect R1 to R8), the temperature and concentrations of nutrient salts fell abruptly; in contrast, the western water mass (Transect R11 to R18) warmed up rapidly and became enriched in nitrates, phosphates and silicates (Fig 3). Beyond $66^{\circ} 30^{\prime} \mathrm{S}$, the characteristics of the 2 water masses changed concurrently with a noticeable enrichment of nitrates and silicates and a decrease in phosphates at $66^{\circ} 20^{\prime}$ In general, the eastern waters remained slightly warmer and richer in nitrates and silicates even though phosphates and $\mathrm{POC}$ were the highest in the east (Fig. 3)

\section{Phytoplankton}

Surface chl a values showed a steady decrease from coastal to offshore areas, reaching their lowest value $\left(0.2 \mathrm{mg} \mathrm{m}^{-3}\right)$ at Stn R18 located $70 \mathrm{~km}$ offshore (Fig. 4). In the vicinity of the coast, chl a ranged from 0.6 to $1.8 \mathrm{mg} \mathrm{m}^{-3}$ with a slight increasing gradient from south to north (Fig. 5). Due to the shallow depth, chlorophyll biomass was quite homogeneous throughout the water column. An exception was found in the vicinity of an important Adélie penguin rookery (Stns 1 to 6 ). Samples gave high values of chl $a$ and ATP which showed a significant increase with depth (from 1.2 to
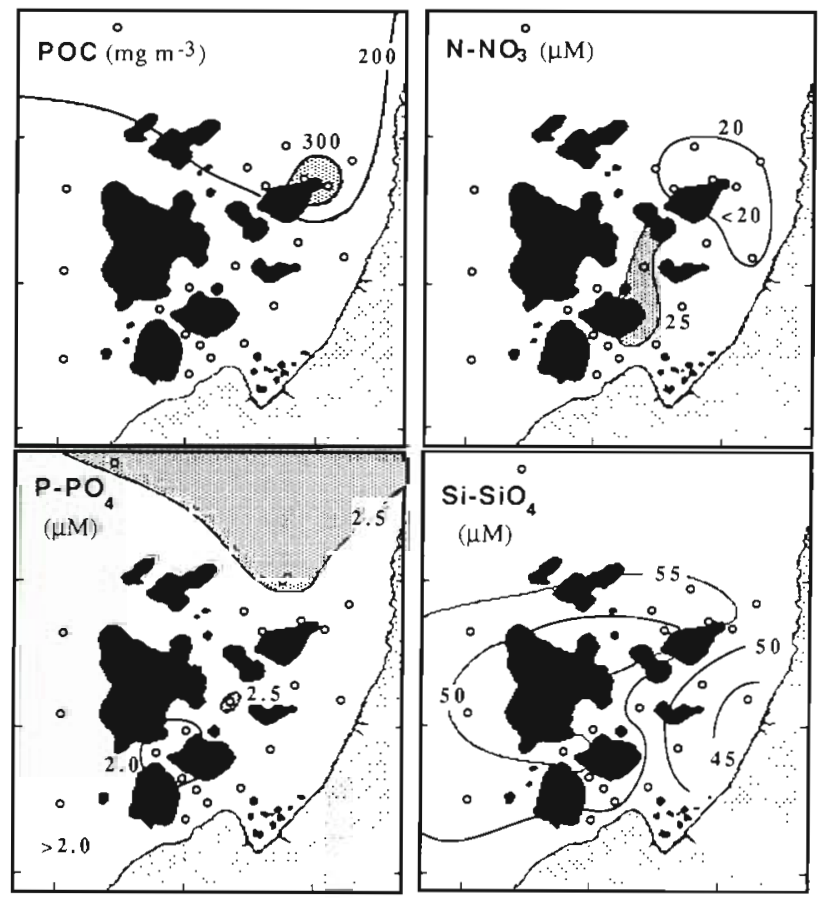

Fig. 2. Spatial distribution of POC, nitrate, phosphate and silicate concentrations in the coastal area of Pointe Geologie Archipelago 


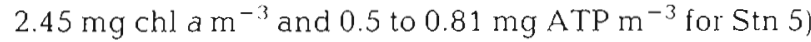
(Fig. 6). This increase in biomass corresponded to an uptake of inorganic phosphate and nitrate (Fig. 6) and may also be related to the high concentrations of 'regenerated' nitrogen $\left(\mathrm{NH}_{4}\right)$ induced by bird manuring (Delille 1990b).

Size fractionation showed that the coastal phytoplankton of Pointe Géologie Archipelago was essentially composed of large sized cells (due to the similarity of the 21 coastal stations studied, results for the different size classes are not presented; they were identical to those for Stns R1, R2 \& R13 shown in Fig. 7). Species larger than $10 \mu \mathrm{m}$ accounted for more than $80 \%$ of the total biomass while the fraction between 3 and $10 \mu \mathrm{m}$ averaged $10 \%$ (Fig. 7). Large sized diatoms, such as Corethron criophilum, Chaetoceros dichaeta, C. acicularis and Nitzschia kerguelensis (with a chl c: chl a ratio between 0.14 and 0.21 ), dominated. In the vicinity of penguin rookeries, where the highest bio- mass was recorded, the distribution of large cells was homogeneous throughout the water column (Table 2). In contrast, the 3-10 $\mathrm{um}$ fraction decreased with depth even though the picoplanktonic fraction $(<3 \mu \mathrm{m})$ increased (except at Stn 5).

Moving progressively away from the coast, in parallel with a reduction in biomass, a decrease in the proportion of species $>10$ um to the benefit of smaller species occurred. From $66^{\circ} 20^{\prime} \mathrm{S}$, species $>10$ um represented only $38 \%$ of the total biomass, as opposed to $36 \%$ for the $3-10 \mu \mathrm{m}$ fraction and $26 \%$ for the picoplanktonic fraction (Fig. 7). Microscopic examination of samples from offshore waters (Stns R16, R17 \& R8) confirmed the scarcity of large size species and the presence of small species $\leq 5 \mu \mathrm{m}$, such as the diatom Nitzschia sp. and some Cryptophyceae and flagellates.

In coastal waters, the phaeopigments were low. The chl a degradation ratio (phaeo a/(chl a + phaeo a), \% ] showed that these planktonic cells were in good condi-
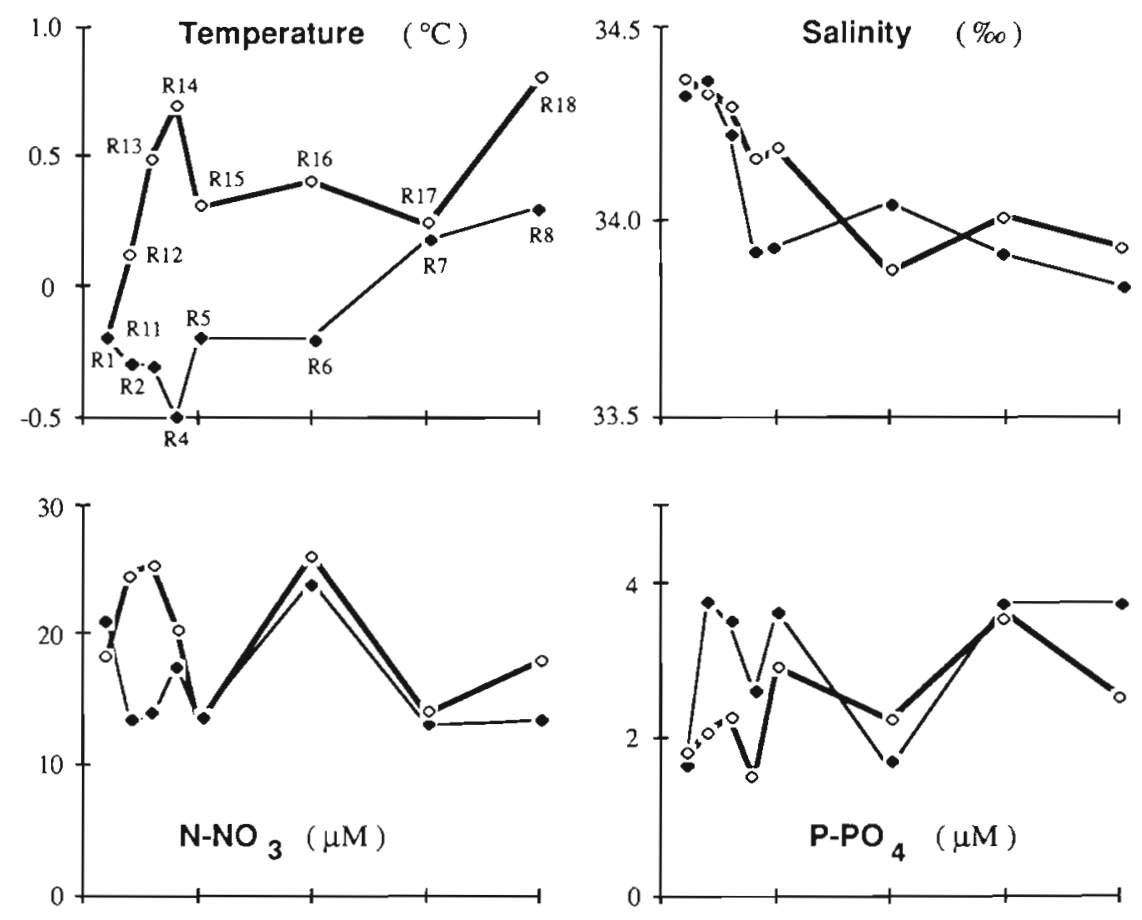

Fig. 3. Variation in the physico-chemical data in the surface waters along the 2 offshore transects between $66^{\circ} 40^{\prime} \mathrm{S}$ and $66^{\circ} 00^{\prime} \mathrm{S}$
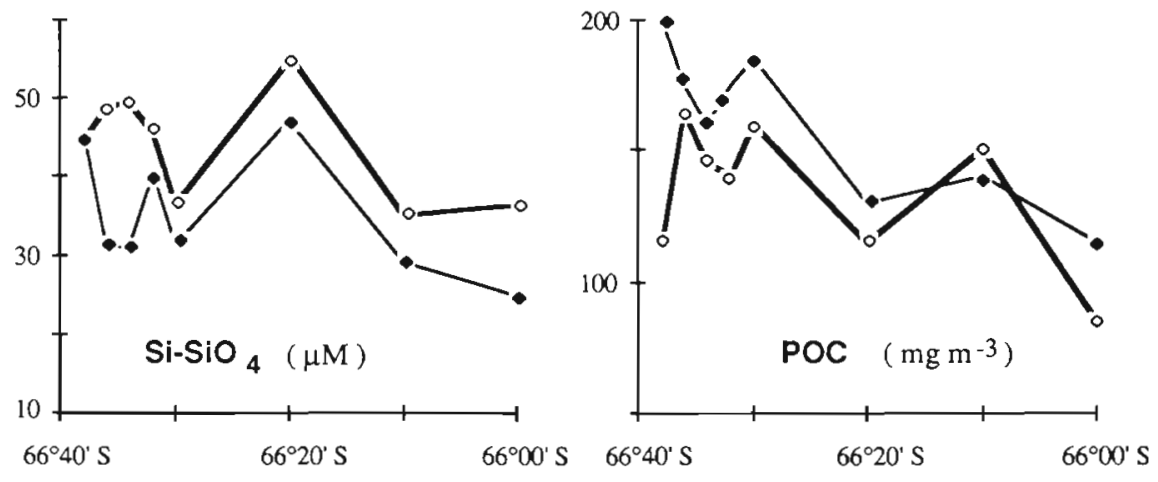

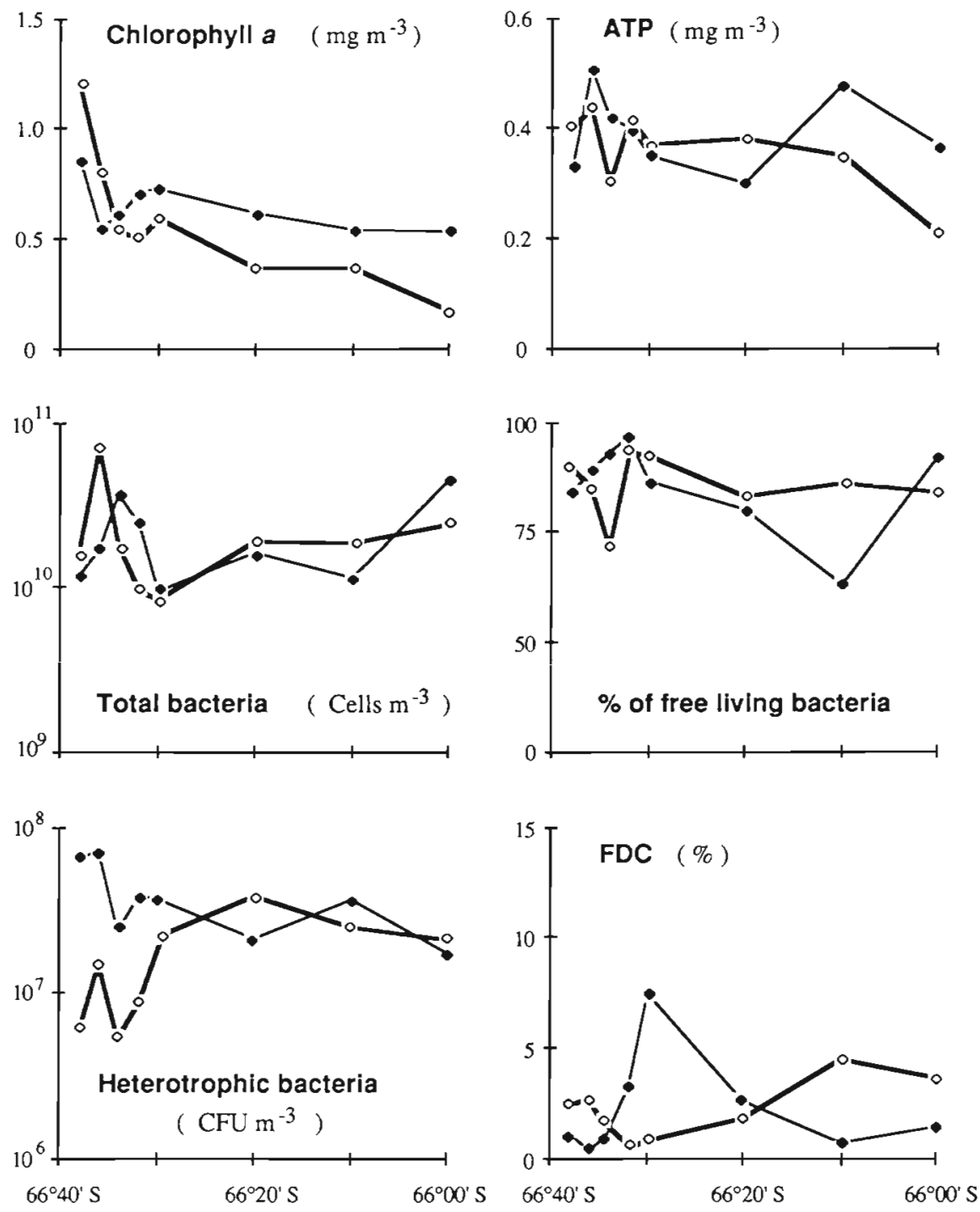

Fig. 4. Variation in the biological data in the surface waters along the 2 offshore transects between $66^{\circ} 40^{\prime} \mathrm{S}$ and $66^{\circ} 00^{\prime} \mathrm{S}$

tion with the 3-10 $\mathrm{um}$ fraction having the lowest ratio (Table 3). The only exception was in the vicinity of penguin rookeries with a mean degradation ratio of about $30 \%$ throughout the water column.

\section{Abundance of bacteria}

Values for total bacterial counts ranged from $9.4 \times$ $10^{9}$ to $1.0 \times 10^{11}$ cells $\mathrm{m}^{-3}$ (Figs. $4 \& 5$ ). Counts of cultivable heterotrophic bacteria were typically 2 or 3 orders of magnitude less than total counts, but both estimates varied considerably with sampling area. No apparent differences were found between total bacterial counts recorded from the 2 transects. After a sharp increase between $66^{\circ} 38^{\prime} \mathrm{S}$ and $66^{\circ} 34^{\prime} \mathrm{S}$, bacterial numbers decreased dramatically between $66^{\circ}$ $34^{\prime} \mathrm{S}$ and $66^{\circ} 30^{\prime} \mathrm{S}$ and then increased gradually in the northern part of the transects. In contrast, FDC and heterotrophic counts greatly differed in the southern parts of the 2 transects with much higher values recorded from the western transect. In the archipelago, highest numbers of bacteria were recorded in the immediate vicinity of penguin rookeries, while lowest numbers were recorded in offshore areas. A similar trend was observed for the ratio of particle associated bacteria to free living bacteria and FDC, the latter decreasing from very high values (close to $10 \%$ ) near the penguins rookeries to much lower values in offshore areas $(<1 \%)$. In contrast with previous work in the same area (Delille et al. 1988, Delille 1990a, b), the 2 incubation procedures used for heterotrophic bacterial estimation yielded different results. Mean values (Table 1) recorded for psychrophilic-psychrotrophic bacteria were significantly higher than those observed for psychrotrophic-mesophilic bacteria. Both kinds of 
Table 2. Relative proportion of chl a (in $\%$ ) in the different planktonic size fractions ( $\mu \mathrm{m})$ throughout the water column for 3 coastal stations located in the vicinity of penguin rookeries

\begin{tabular}{|c|c|c|c|c|c|c|c|c|c|}
\hline \multirow[t]{2}{*}{$\begin{array}{l}\text { Depth } \\
(\mathrm{m})\end{array}$} & \multicolumn{3}{|c|}{$\begin{array}{c}\operatorname{Stn} 4 \\
\text { Size fractions }\end{array}$} & \multicolumn{3}{|c|}{$\begin{array}{c}\text { Stn } 5 \\
\text { Size fractions }\end{array}$} & \multicolumn{3}{|c|}{$\begin{array}{c}\text { Stn } 6 \\
\text { Size fractions }\end{array}$} \\
\hline & $>10$ & $3-10$ & $<3$ & $>10$ & $3-10$ & $<3$ & $>10$ & $3-10$ & $<3$ \\
\hline 0 & 80.1 & 10.4 & 9.5 & 87.0 & 8.0 & 5.0 & 89.3 & 8.4 & 2.3 \\
\hline 10 & 82.0 & 11.9 & 6.1 & 89.3 & 2.8 & 7.9 & 85.0 & 8.0 & 7.0 \\
\hline 20 & 84.8 & 8.2 & 7.0 & 75.0 & 10.0 & 15.0 & 89.8 & 4.5 & 5.7 \\
\hline 30 & 80.4 & 6.1 & 13.5 & 80.8 & 8.9 & 10.3 & 88.7 & 5.1 & 6.2 \\
\hline 50 & - & - & - & - & - & - & 88.5 & 5.9 & 5.6 \\
\hline
\end{tabular}

microflora attained their greatest values in the immediate vicinity of penguin rookeries, but a second enriched area of psycrophylic-psychrotrophic bacteria was observed in the vicinity of recently melted sea ice (Fig. 5). While there was very little variation in numbers of psychrophilic-psychrotrophic bacteria with increasing depth, a significant decrease in densities of psy-

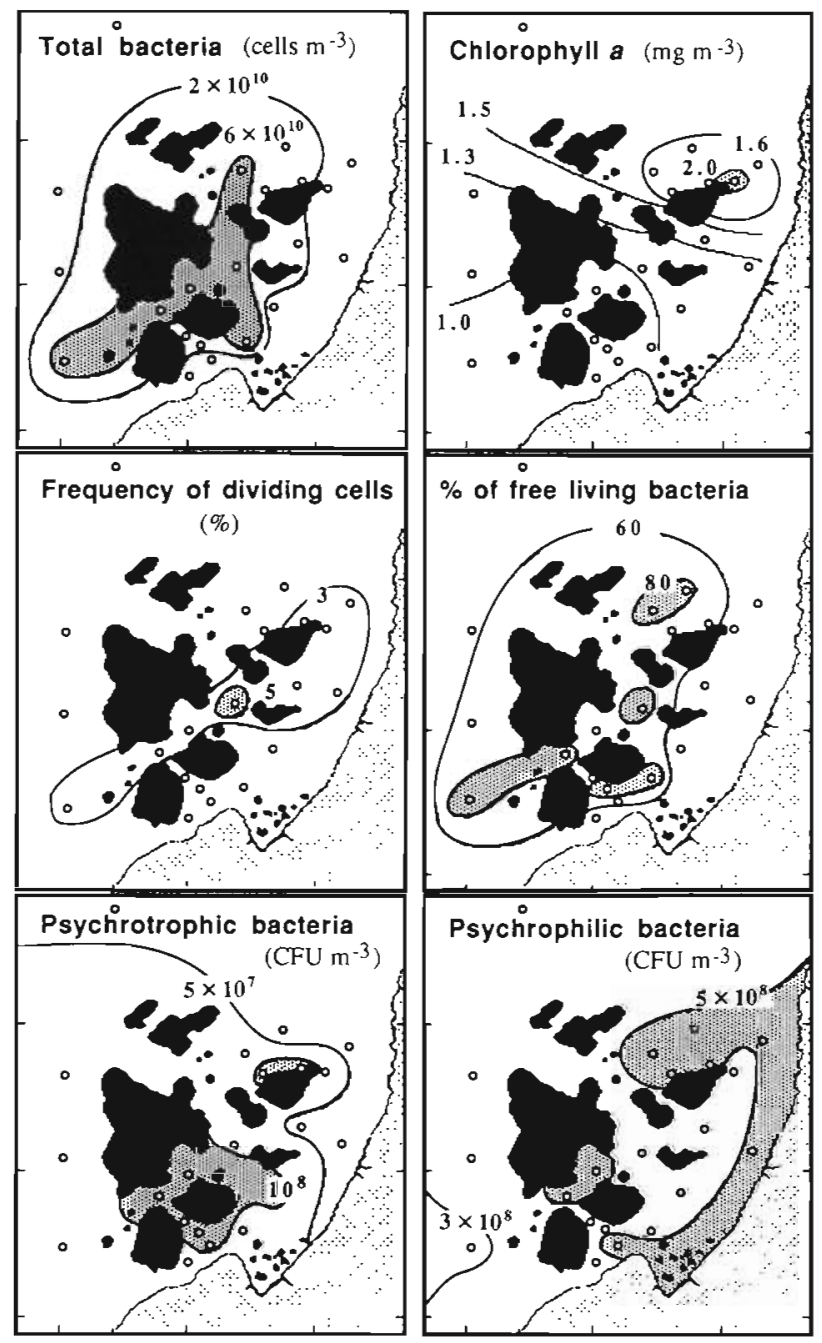

Fig. 5. Spatial distribution of the biological data in the coastal area of Pointe Géologie Archipelago chrotrophic-mesophilic bacteria was observed at the deepest station (Fig. 6).

\section{Ratio of bacterial and phytoplankton biomass}

The comparison between total bacterial cell numbers and chl a concentrations for the samples collected during our study reveals no direct correlation $\left(\mathrm{r}^{2}=0.25\right.$ $\mathrm{n}=59$ ). In the absence of direct information, we have followed Neori \& Holm-Hansen (1982) in using a carbon : chl a ratio of 60 and a carbon: ATP ratio of 250 . Obviously, the absolute magnitude of the ratio of bacterial and algal biomass is dependant on the consistency of these estimates. Although mean cell volume of bacteria $\left(0.08 \mu \mathrm{m}^{3}\right)$ is small relative to phytoplankton, bacterial biomass estimated using a conversion factor of $0.4 \mathrm{pgC} \mathrm{mm}^{-3}$ (Bjørnsen \& Kuparinen 1991) constitutes a significant fraction of the total bacterial/phytoplankton biomass. Bacterial biomass expressed as a percentage of phytoplankton biomass thus accounted for between 2\% (Stn R16) to 15\% (Stn R9) of total biomass in offshore waters and between $1 \%$ (Stn 1) to $30 \%$ (Stn 19) in the vicinity of the archipelago.

\section{DISCUSSION}

If the levels of measured bacterial parameters are compared to the relevant published data (Hanson et al. 1983, Painting et al. 1985, Kottmeier et al. 1987, Rivkin et al. 1989, Karl et al. 1991), it can be seen that the bacterial abundance and biomass were relatively low

Table 3. Mean degradation ratio (phaeo a/chl a + phaeo a) in the different planktonic size fractions in surface waters of Pointe Géologie Archipelago

\begin{tabular}{cc|}
$\begin{array}{c}\text { Size fractions } \\
(\mu \mathrm{m})\end{array}$ & $\begin{array}{c}\text { Mean degradation ratio } \\
(\%)\end{array}$ \\
& \\
$3-10$ & 15 \\
$<3$ & 9 \\
\hline
\end{tabular}




\begin{tabular}{|c|c|c|c|c|c|}
\hline$\prod_{0}^{\text {Temperature }}$ & $\begin{array}{c}\mathrm{N}-\mathrm{NO}_{3} \\
\mu M\end{array}$ & $\begin{array}{l}\mathrm{POC} \\
\mathrm{mg} \mathrm{m}^{-3}\end{array}$ & $\begin{array}{l}\mathrm{Chl} \mathrm{a} \\
\mathrm{mgm}^{-3}\end{array}$ & $\begin{array}{l}\text { Het. bact. } \\
\text { CFU } m^{-3}\end{array}$ & $\begin{array}{l}\text { Tot. bact. } \\
\text { Cells } m^{\cdot 3}\end{array}$ \\
\hline i Salinity & $\begin{array}{l}\mathrm{P}-\mathrm{PO} 4 \\
\mu \mathrm{M}\end{array}$ & $\begin{array}{c}\mathrm{Si}-\mathrm{SiO} \\
\mu M\end{array}$ & $\begin{array}{l}\text { ATP } \\
\mathrm{mgm}^{-3}\end{array}$ & $\begin{array}{l}\text { Psyc. bact. } \\
\text { CFU } m^{-3}\end{array}$ & $\begin{array}{c}\text { Free bact. } \\
\%\end{array}$ \\
\hline
\end{tabular}
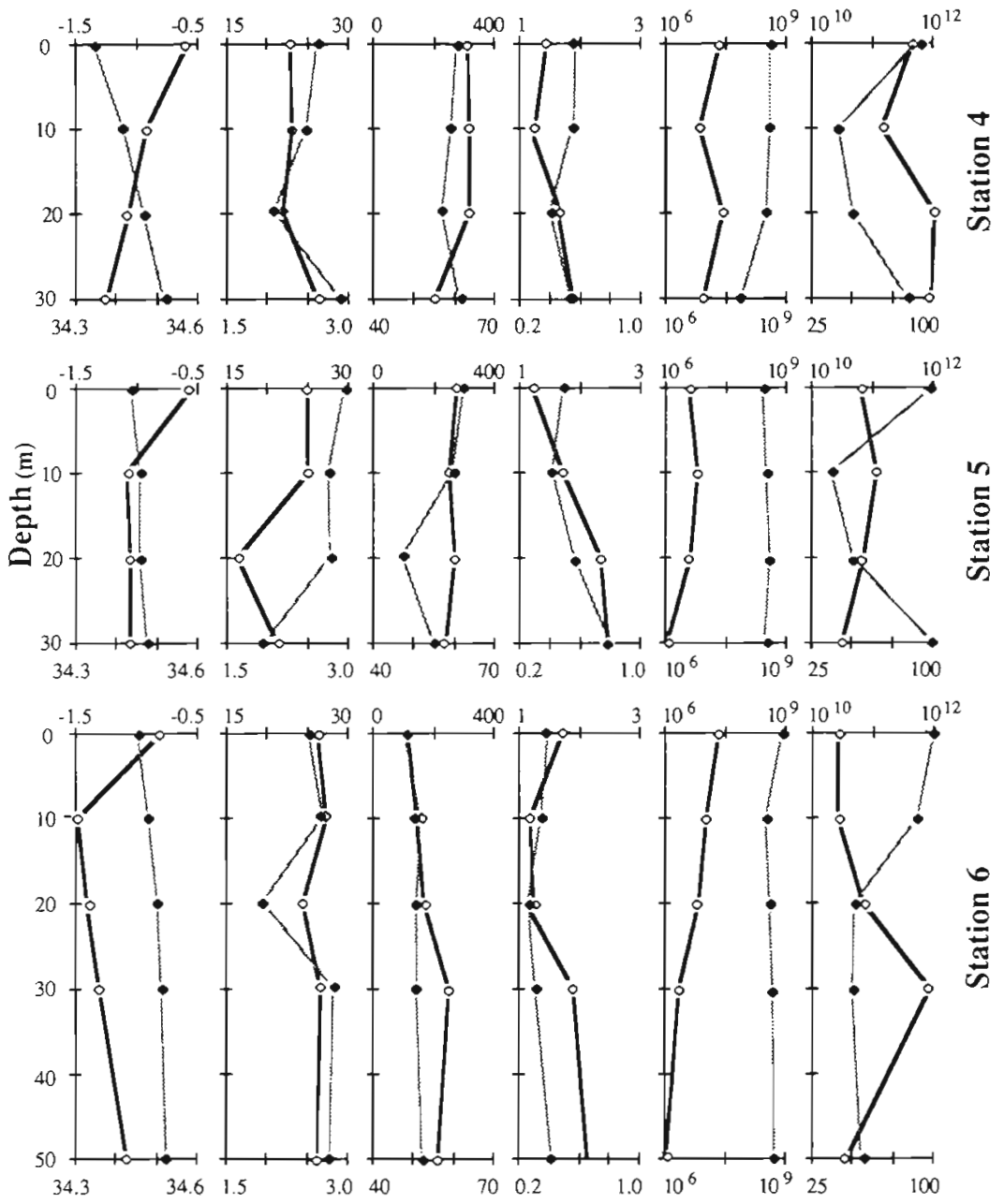

Fig. 6. Vertical profiles of physico-chemical and biological parameters for 3 representative coastal stations (Stns 4,5 \& 6) in the vicinty of penguin rookeries

R 13

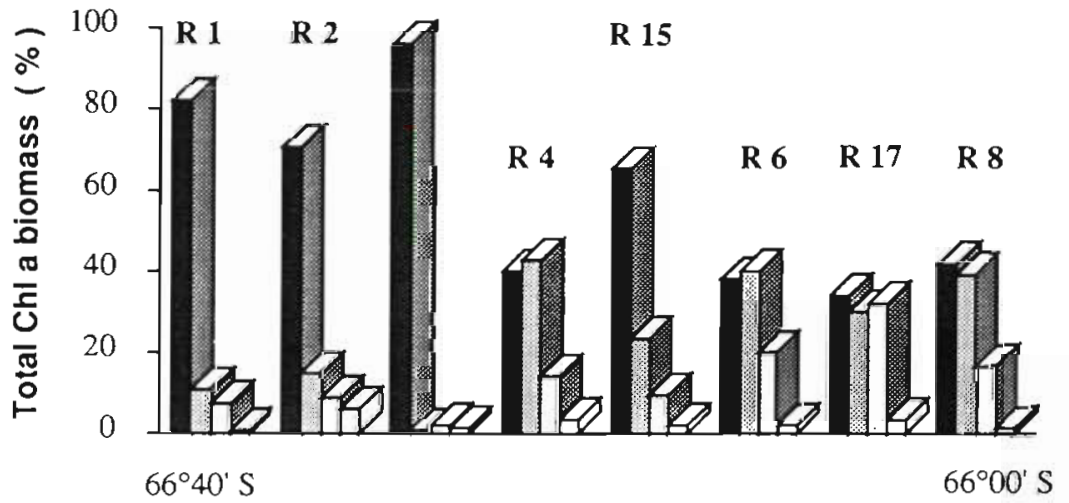

FIg. 7 Varlation in the relative proportion of surface chl a in the different phytoplankton size fractions recorded between $65^{\circ} 40^{\prime} \mathrm{S}$ and $66^{\circ} 00^{\circ} \mathrm{S}$ 
but similar to other Antarctic data. In contrast, heterotrophic bacterial numbers in coastal samples located near the major penguin rookery had higher values when compared with typical oceanic values. FDC values which were recorded in the immediate vicinity of penguin rookeries correspond to mean values reported in the Antarctic Ocean (Hanson et al. 1983). Despite conditions such as reduced wind disturbance, high solar irradiance and high nutrient levels which could potentially support high phytoplankton growth, the studied coastal waters support relatively low levels of algal biomass. Chl a biomass were higher than values reported for Antarctic oceanic waters, which typically fall in the range of 0.1 to $1.0 \mathrm{mg} \mathrm{m}^{-3}$ (Weber \& El-Sayed 1987, Nelson et al. 1989). But, except for the samples located in the immediate vicinity of penguin rookeries, they were lower than other observed coastal Antarctic values (El-Sayed \& Taguchi 1981, Krebs 1983, HolmHansen et al. 1989). Numerous hypothesis have been put forward to explain the low production of Antarctic waters (Sakshaug \& Holm-Hansen 1984, Priddle et al. 1986, Jacques 1989). Recently Martin \& Fitzwater (1988) have suggested that iron is responsible for biomass limitation, but this hypothesis is controversial (Sunda et al. 1991). In fact, it seems that temperature (Neori \& Holm-Hansen 1982, Tilzer et al. 1986, Fiala \& Oriol 1990) and light levels (Holm-Hansen et al. 1989) are the most important factors in controlling Antarctic phytoplankton biomass.

Calculated ratios between bacterial and algal biomass are consistent with the few field data that are available (Mullins \& Priddle 1987) and are in agreement with the general assumption that bacterial microflora averages about $20 \%$ of the total microbial population (Cole et al. 1988). Assuming that aquatic bacteria have a $50 \%$ carbon-based growth efficiency (Suttle et al. 1991), the Antarctic coastal heterotrophic microflora, which exhibits relatively short generation times (Delille et al. 1988, Rivkin et al. 1989), may require a proportionally large flux of organic matter from the primary producers, either directly via phytoplankton exudate or more likely indirectly through the action of zooplankton grazing.

Although several examples of correlations between bacterial and phytoplankton have been reported (Fuhrman et al. 1980, Bird \& Kalff 1984, Cole et al. 1988. Tobiesen 1991), such correlations may depend on the scale of the observations (McManus \& Peterson 1988). It is therefore not wholly unexpected that the overall relationships between bacterial and phytoplankton biomass show no clear trends as previously reported for Antarctic waters (Bölter 1987, Mullins \& Priddle 1987. Karl et al. 1991, Maki \& Herwig 1991). However, bacterial productivity should be better explained in terms of primary production rather than algal biomass (Cole et al. 1988, Lignell 1990). Bacteria or phytoplankton maxima and minima were local events superimposed upon more subtle larger scale-differences. A lack of direct interrelationships between bacteria and phytoplankton may also be related to different time lags between presence of nutrients and their use by different consumers.

The samples in this study covered variations of large scales. Large-scale variability may be linked to differences in water mass characteristics. This variation would have been well-established over long time scales corresponding to the growth season of the algae which may be related to the retreat of pack ice or other physical processes. When released from ice, the icebound organic matter may act as an inoculum for the water column (Ackley et al. 1979, Garrison et al. 1987. Smith \& Clement 1990). However, this important theory of the role of sea ice is not entirely supported by the present coastal observations. Despite the extreme cold, previous studies in the same area have demonstrated a strong similarity between heterotrophic data obtained for seawater samples incubated at $2{ }^{\circ} \mathrm{C}$ for $20 \mathrm{~d}$ or $15^{\circ} \mathrm{C}$ for $10 \mathrm{~d}$ (Bouvy \& Delille 1988, Delille et al. 1988). This similarity is in agreement with numerous observations which clearly indicate that a large majority of the Antarctic bacterial strains isolated from seawater must be considered as psychrotrophic and not as true psychrophiles (Inoue \& Komagata 1976, Delille \& Perret 1989). Most reported observations of true marine bacterial psychrophiles come from relatively deep sediment (Reichard 1988, Rüger 1989) or from sea-ice communities (Kottmeier \& Sullivan 1988, Delille 1992). In the present study the observed discrepancy between psychrophilic-psychrotrophic and psychrotrophicmesophilic bacterial counts may be related to the recent melting of the sea ice present in the eastern part of studied area. On the other hand, there were no indications of any influence of this recent melting on the neritic phytoplankton which was essentially constituted of large size pelagic diatoms (notably Nitzschia kerguelensis). However, if pack ice microalgae have the potential to make a significant contribution to the primary production in the southern ocean, land fast ice may have a more limited influence (Lizotte \& Sullivan 1991).

Superimposed upon this pattern were shorter timescale changes associated with local phenomena, such as bird manuring. In coastal waters, abundant marine bird-life is a clearly identifiable source of nutrients (Downes et al. 1986, Delille 1987). All the bacterial data (total and heterotrophic counts, FDC) and some of the phytoplankton data confirmed the horizontal patchiness previously reported for the area by Delille (1990b). The seston enrichment induced by bird manuring seems sufficient to sustain the large bacterial biomass 
observed in the coastal area. In the same way, the relative preponderance in the coastal area of particleassociated bacteria, as opposed to free-living bacteria, is probably related to POC enrichment. However, these effects are limited to the immediate vicinity of the bird rookeries.

The size distribution of the primary producers plays an important role in the overall community structure and trophic organization of marine ecosystems (Harrison 1986). It was generally considered that phototrophic nanoplankton accounted for the major part of the biomass and productivity of marine phytoplankton in the world ocean but the smaller phytoplankters can also play an important role. In the Antarctic Ocean, the distribution of the size structure of phytoplankton is poorly understood. Generally, nanoplankton are dominant but a significant role may be accorded to picoplankton (Hewes et al. 1985, Weber \& El-Sayed 1987, Jacques \& Panouse 1991). Our study shows that the distribution of phytoplankton in the neritic area of Terre Adélie is not homogeneous. There is a decrease in the size of the populations moving from the coast to offshore. In the vicinity of the continental shelf where biomass is highest, large diatoms predominate, even though offshore, a decrease in biomass is accompanied by a change in size structure with the dominance of species smaller than $10 \mu \mathrm{m}$

Considering the relationships between bacterioplankton and phytoplankton, the investigated area may be divided into 2 main zones which may have implications for the structure of the pelagic food web. Firstly, in the coastal area, especially in the vicinity of large penguin rookeries, bacteria seems to be mainly dependant on supplies of allochthonous organic matter derived from bird manuring; the large nanoplankton fraction is only slightly utilized by bacteria and lost through sedimentation and zooplankton grazing. Secondly, in the ompoverished offshore area, the dominant phytoplankton fractions less than $10 \mu \mathrm{m}$ form part of a microbial food chain with many trophic levels. Due to this microbial loop (Azam et al. 1983) an indirect relationship between algae and bacteria may be expected.

Acknowledgements. This research was supported by the 'Terres Australes et Antarctiques Françaises' and 'Expeditions Polaires Françaises' Special thanks are due to L. Mallard and $P$. Glevarec who helped in the collection and analyses of the samples in the field. We are grateful to L. Oriol for her technical assistance and $M$.-J. Dinet for species determination.

\section{LITERATURE CITED}

Ackley, S. F, Buck, K. R., Taguchi, S. (1979). Standing crop of algae in the sea ice of the Weddell Sea region. Deep Sea Res. 26A: 269-281
Azam, F., Fenchel, T., Field, J. G., Gray, J. S., Meyer-Reil, L. A., Thingstad, F. (1983). The ecological role of watercolumn microbes in the sea. Mar Ecol. Prog. Ser. 103 $257-263$

Berman, T., Nawrocki, M., Taylor, G. T., Karl, D. M. (1987). Nutrient flux between bacteria, bacterivorous nanoplanktonic protists and algae. Mar. microb. Fd Webs 2: 69-82

Bird, D. F., Kalff, J. (1984). Empirical relationships between bacterial abundance and chlorophyll concentration in fresh and marine waters. Can. J. Fish. Aquat. Sci. 41: $1015-1023$

Bjornsen, P. K., Kuparinen, J. (1991). Determination of bacterioplankton biomass, net production and growth efficiency in the Southern Ocean. Mar Ecol. Prog. Ser. 71. 185-194

Bölter, M. (1987). Microbiological, planktonic and chemical characteristics and their validity for separation of water masses in the Bransfield Strait, Antarctica. S. Afr J. mar. Sci. 5: 133-143

Bouvy, M., Delille, D. (1988). Spatial and temporal variations of Antarctic and Subantarctic bacterioplankton. Neth. J Sea Res. 22: 139-147

Caron, D. A., Davis, P. G., Sieburth, J. McN. (1989). Factors responsible for the differences in cultural estimates and direct microscopical counts of populations of bacterivorous nanoflagellates. Microb. Ecol. 18: 89-104

Cole, J. J., Findlay, S., Pace, M. L. (1988). Bacterial production in fresh and saltwater ecosystem: a cross-system overview. Mar. Ecol. Prog. Ser. 43: 1-10

Delille, D. (1987). Spatial distribution of coastal Antarctic seawater bacteria: relationship with avifauna. Polar Biol 8: $55-60$

Delille, D. (1990a). Seasonal changes of Subantarctic heterotrophic bacterioplankton. Arch. Hydrobiol. 119: 267-277

Delille, D. (1990b). Factors affecting the horizontal patchiness of coastal Antarctic seawater bacteria. Polar Biol. 11: 41-45

Delille, D. (1992). Marine bacterioplankton at the Weddell Sea ice edge, distribution of psychrophilic and psychrotrophic populations. Polar Biol. 12: 205-210

Delille, D., Bouvy, M. (1989). Bacterial responses to natural organic inputs in marine Subantarctic area. Hydrobiologia 182: $225-238$

Delille, D., Bouvy, M., Cahet, G. (1988). Short term variations of bacterioplankton in Antarctic zone: Terre Adélie area. Microb. Ecol. 15: 293-309

Delille, D., Perret, E. (1989). Influence of temperature on the growth potential of southern polar marine area. Microb. Ecol. 18: 117-123

Downes, M. T., Howard-Williams, C., Vincent, W. F. (1986) Sources of organic nitrogen, phosphorus and carbon in Antarctic streams. Hydrobiologia 134: 215-225

Ducklow, H. W., Purdie, D. A., Williams, P. J. LeB., Davies, J. M. (1986). Bacterioplankton: a sink for carbon in a coastal marine plankton community. Science 232: 865-867

El-Sayed, S. Z., Taguchi, S. (1981). Primary production and standing crop of phytoplankton along the ice edge in the Weddell Sea. Deep Sea Res. 28: 1017-1032

Fiala, M., Oriol, L. (1990). Light-temperature interactions on the growth of Antarctic diatoms. Polar Biol. 10: 629-636

Fuhrman, J. A., Ammerman, J. W., Azam. F. (1980). Bacterioplankton in the coastal euphotic zone: distrıbution, activity and possible relationships with phytoplankton. Mar. Biol. 60: 201-207

Garrison, D. L., Buck, K. R., Fryxell, G. A. (1987). Algal assemblages in Antarctic pack ice and ice-edge plankton. J. Phycol. 23: 564-572

Gordon, A. L., Tchemia P. (1972). Waters of the continental 
margin off Adélie coast, Antarctica. In: Hayes, D. E. (ed.) Antarctic oceanography II: The Australian-New Zealand Sector, Antarct. Res. Ser., Vol. 19. American Geophysical Union, Washington, DC, p. 59-69

Hagström, A., Larsson, V., Horsted, P., Normark, S. (1979). Frequency of dividing cells, a new approach to the determination of bacterial growth rates in aquatic environments. Appl environ. Microbiol. 37 805-812

Hanson, R. B., Schafer, D., Ryan, T., Pope, D. H., Lowery, H. K (1983). Bacterioplankton in Antarctic ocean waters during late Austral winter abundances, frequency of dividing cells, and estimates of production. Appl. environ. Microbiol. 45: 1622-1632

Harris, G. P. (1986). Phytoplankton ecology. Structure, function and fluctuation. Chapman \& Hall, New York

Harrison, W. G. (1986). Respiration and its size-dependence in microplankton populations from surface waters of the Canadian Arctic. Polar Biol. 6: 145-152

Hewes, C. D., Holm-Hansen, O., Sakshaug, E. (1985). Alternate carbon pathways at lower trophic levels in the Antarctic food web. In: Siegfried, W. R., Condy, P. R., Laws, R. M. (eds.) Antarctic nutrient cycles and food webs. Springer, Berlin. p. 277-283

Hewes, C. D., Sakshaug, E., Reid, F. M. H., Holm-Hansen, O. (1990). Microbial autotrophic and heterotrophic eucaryotes in Antarctic waters: relationships between biomass and chlorophyll, adenosine triphosphate and particulate organic carbon. Mar Ecol. Prog. Ser. 63: 27-35

Hobbie, J. E., Daley, R. J., Jasper, S. (1977). Use of nuclepore filters for counting bacteria by fluorescence microscopy. Appl environ. Microbiol. 33: 1225-1228

Holm-Hansen, O. (1973). Determination of total microbial biomass by measurement of adenosine triphosphate. In: Stevenson, L. H., Colwell R. R.(eds.) Estuarine microbial ecology. Univ. South Carolina Press, Columbia, p. 73-89

Holm-Hansen, O., Booth, C. R. (1966). The measurement of adenosine triphosphate in the ocean and its ecological significance. Limnol. Oceanogr. 11: 510-519

Holm-Hansen, O., Mitchell, B. G.. Hewes, C. D., Karl, D. M. (1989). Phytoplankton blooms in the vicinity of Palmer Station, Antarctica. Polar Biol 10: 49-57

Inoue, K., Komagata, K. (1976). Taxonomic study on obligately psychrophilic bacteria isolated from Antarctica. J. gen. appl. Microbiol. 22: 165-178

Jacques, G. (1989). Primary production in the open Antarctic Sea during the Austral summer. A review. Vie Milieu 39: $1-17$

Jacques, G., Panouse, M. (1991). Biomass and composition of size fractionated phytoplankton in the Weddell-Scotia Confluence area. Polar Biol. 11. 315-328

Jumars, P. A., Perry, D. L., Baross, J. A., Perry, M. J., Frost, B W (1989). Closing the microbial loop: dissolved carbon pathway to heterotrophic bacteria from incomplete ingestion, digestion and absorption in animals. Deep Sea Res. 36: 483-495

Karl, D. M., Holm-Hansen, O., Taylor, G. T., Tien, G., Bird, D. F. (1991). Microbial biomass and productivity in the western Bransfied Strait, Antarctica during the 1986-87 Austral summer. Deep Sea Res. 89: 1029-1055

Kottmeier, S. T., Grossi, S. W., Sullivan, C. W (1987). Sea ice microbial communities. VIII. Bacterial production in annual of McMurdo Sound, Antarctica. Mar Ecol. Prog. Ser. 35: 175-186

Kottmeier, S. T., Sullivan, C. W. (1988). Sea ice microbial communities. 9. Effects of temperature and salinity on rates of metabolism and growths of autotrophs and heterotrophs. Polar Biol. 8: 293-304
Krebs, W. N. (1983). Ecology of neritic marine diatoms, Arthur Harbor, Antarctica. Micropaleontology 29: 267-297

Kuosa, H., Kivi, K. (1989). Bacteria and heterotrophic flagellates in the pelagic carbon cycle in the northern Baltic Sea. Mar. Ecol. Prog. Ser 53: 93-100

Lancelot, C., Billen, G. (1984). Activity of heterotrophic bacteria and its coupling to primary production during the spring phytoplankton bloom in the Southern Bight of the North Sea. Limnol. Oceanogr 29: 721-730

Lignell, R. (1990). Excretion of organic carbon by phytoplankton: its relation to algal biomass, primary productivity and bacterial secondary productivity in the Baltic Sea. Mar. Ecol. Prog. Ser. 68: 85-99

Lizotte, M. P., Sullivan, C. W (1991). Photosynthesisirradiance relationships in microalgae associated with Antarctic pack ice: evidence for in situ activity. Mar Ecol. Prog. Ser. 71: 175-184

McManus, G. B., Peterson, W. T. (1988). Bacterioplankton production in the nearshore zone during upwelling off central Chile. Mar. Ecol. Prog. Ser. 43: 11-17

Maki, J. S., Herwig R. P. (1991). A diel study of the neuston and plankton bacteria in an Antarctic pond. Antarctic Sci. 3: $47-51$

Martin, J. H., Fitzwater, S. E. (1988). Iron-deficiency limits phytoplankton growth in the north-east Pacific subarctic. Nature 331. 341-343

Mullins, B. W., Priddle. J. (1987). Relationships between bacteria and phytoplankton in the Bransfield Strait and southern Drake passage. Br Antarct. Surv. Bull. 76: 51-64

Nelson, D. M., Smith, W. O., Jr, Gordon, L. I., Huber, B. A. (1987). Spring distributions of density, nutrients and phytoplankton biomass in the ice-edge zone of the WeddellScottia Sea. J geophys. Res. 92: 7181-7190

Nelson, D. M., Smith, W. O. Jr, Muench, R. D., Gordon, L. I. Sullivan, C. W., Husby, D. M. (1989). Particulate matter and nutrient distributions in the ice-edge zone of the Weddell sea: relationship to hydrography during late summer. Deep Sea Res. 36: 191-209

Neori, A., Holm-Hansen, O. (1982). Effect of temperature on rate of photosynthesis in Antarctic phytoplankton. Polar Biol. 1: 33-38

Neveux, J., Panouse M. (1987). Spectrofluorometric determination of chlorophylls and pheophytins. Arch. Hydrobiol. 109: $567-581$

Newell, S. Y., Christian, R. R. (1981). Frequency of dividing cells as an indicator of bacterial productivity. Appl. environ. Microbiol 42: 23-31

Oppenheimer, C. H., ZoBell, C. E. (1952). The growth and viability of sixty-three species of marine bacteria as influenced by hydrostatic pressure. J. mar. Res. 11 10-18

Painting, S. J., Lucas, M. I., Stenton-Dosey, J. M. E. (1985). The South African SIBEX I cruise to the Prydz Bay region, 1984. X. Biomass and production of bacterioplankton in Prydz Bay, Antarctica, and phytoplankton, detritus and bacterial relationships. S. Afr T. Nav. Antarkt. 15: $42-52$

Pick, F. R., Caron, D. A. (1987). Picoplankton and nanoplankton biomass in Lake Ontario: relative contribution of phototrophic and heterotrophic communities. Can. J. Fish. Aquat. Sci. 44: 2164-2172

Priddle, J., Hawes, I., Ellis-Evans, J. C. (1986). Antarctic aquatic ecosystems as habitats for phytoplankton. Biol. Rev. 61 : $199-238$

Reichard, W (1988). Impact of the Antarctic benthic fauna on the enrichment of biopolymer degrading psychrophilic bacteria. Microb. Ecol. 15: 311-321

Rheinheimer, G., Gocke, K., Hoppe, H. G. (1989). Vertical 
distribution of microbiological and hydrographic-chemical parameters in different areas of the Baltic Sea. Mar. Ecol. Prog. Ser 52: 55-70

Riemann, B., Sondergaard, G. A. (1986). Regulation of bacterial secondary production in two eutrophic lakes and in experimental enclosures. J. Plankton Res. 8: 519-536

Rivkin, R. B., Putt, M., Alexander, S. P., Meritt, D., Gaudet, L. (1989). Biomass and production in polar planktonic and sea ice microbial communities: a comparative study. Mar Biol. 101: 273-283

Ruger, H.-J. (1989). Benthic studies of the northwest African upwelling region: psychrophilic and psychrotrophic bac. terial communities from areas with different upwelling intensities. Mar. Ecol. Prog. Ser. 57: 45-52

Sakshaug, E., Holm-Hansen, O. (1984). Factors governing pelagic production in polar oceans. In: Holm-Hansen $O$. Bolis, L., Gilles, R. (eds.) Marine phytoplankton and productivity. Springer, Berlin, p. 1-17

Satoh, H., Fukami, K., Watanabe, K., Takahashi, E. (1989). Seasonal changes in heterotrophic bacteria under fast ice near Syowa station, Antarctica. Can. J. Microbiol. 35: 329-333

Sherr, E. B., Rassoulzadegan, F., Sherr, B. F. (1988). Bacterivory by pelagic chereotrichous culates in coastal waters of the NW Mediterranean Sea. Mar. microb. Fd Webs. 1. $61-80$

Smith, N. R., Zhaoqian, D., Kerry, K. R., Wright, S. (1984). Water masses and circulation in the region of Prydz Bay, Antarctica. Deep Sea Res. 31: 1121-1147

Smith, R. E. H., Clement, P. (1990). Heterotrophic and bacterial productivity in assemblages of microbes from sea ice in the high Arctic. Polar Biol. 10: 351-357

Sunda, W G., Swift, D. G., Huntsman, S. A. (1991). Low iron

This article was presented by O. Holm-Hansen,

La Jolla, California, USA requirement for growth in oceanic phytoplankton. Nature 351. 55-57

Suttle, C. A., Chan, A. M., Fuhrman, J. A. (1991). Dissolved free amino acids in the Sargasso Sea: uptake and respiration rates, turnover times, and concentrations. Mar Ecol. Prog. Ser 70: 189-199

Tanoue, E. (1985). Distribution and chemical composition of particulate organic matter in the Pacific sector of the Antarctic Ocean. Trans. Tokyo Univ. Fish. 6: 43-57

Taylor, A. H., Joint, I. (1990). A steady-state analysis of the 'microbial loop' in stratified systems. Mar Ecol. Prog. Ser. 59: $1-17$

Tilzer, M. M., Bodugen, B. von, Smetacek, V. (1985). Lightdependence of phytoplankton photosynthesis in the Antarctic Ocean: implications for regulating productivity. In: Siegfried, W R., Condy, P. R., Laws, R. M. (eds.) Antarctic nutrient cycles and food webs. Springer, Berlin, p. $60-69$

Tilzer, M. M., Elbrächter, M., Gieskes, W. W., Beese, B. (1986). Light-temperature interactions in the control of photosynthesis in Antarctic phytoplankton. Polar Biol 5: 105-111

Tobiesen, A. (1991). The succession of microheterotrophs and phytoplankton within the microbial loop in Oslofjorden, May-October 1984. J. Plankton Res. 13: 197-216

Treguer, P., Le Corre, P. (1975). Manuel d'analyses des sels nutritifs dans l'eau de mer. Utilisation de l'Auto-Analyzer II Technicon, $2^{\circ}$ edn. U.B.O., Brest

Utermöhl, H. (1958). Zur Vervollkommnung der quantitativen Phytoplankton-Methodik. Mitt. Int. Verein. Limnol. 9: 1-38

Weber, L. H., El-Sayed, S. Z. \{1987\}. Contribution of the net, nano- and picoplankton standing crop and primary productivity in the Southern Ocean. J. Plankton Res. 9: 973-994

Manuscript first received: September 5, 1991

Revised version accepted: September 4, 1992 